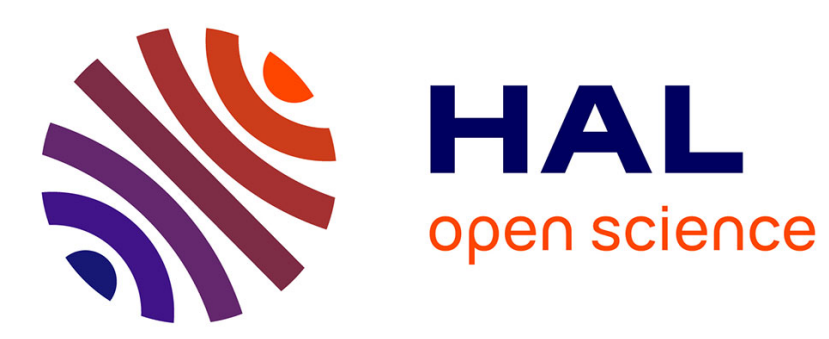

\title{
Local Structure of the Interlayer Ion in Synthetic Fluorine Mica
}

\author{
H. Sakane, M.-O. Okabe, T. Suzuki
}

\section{To cite this version:}

H. Sakane, M.-O. Okabe, T. Suzuki. Local Structure of the Interlayer Ion in Synthetic Fluorine Mica. Journal de Physique IV Proceedings, 1997, 7 (C2), pp.C2-1165-C2-1166. 10.1051/jp4:19972175 . jpa-00255241

\section{HAL Id: jpa-00255241 https://hal.science/jpa-00255241}

Submitted on 1 Jan 1997

HAL is a multi-disciplinary open access archive for the deposit and dissemination of scientific research documents, whether they are published or not. The documents may come from teaching and research institutions in France or abroad, or from public or private research centers.
L'archive ouverte pluridisciplinaire HAL, est destinée au dépôt et à la diffusion de documents scientifiques de niveau recherche, publiés ou non, émanant des établissements d'enseignement et de recherche français ou étrangers, des laboratoires publics ou privés. 


\title{
Local Structure of the Interlayer Ion in Synthetic Fluorine Mica
}

\author{
H. Sakane, M.-O. Okabe and T. Suzuki \\ Department of Applied Chemistry and Biotechnology, Faculty of Engineering, Yamanashi University, \\ Takeda 4-3-11, Kofu, Yamanashi 400, Japan
}

\begin{abstract}
Na}$-form tetrasilicic fluorine micas, i.e., sodium taeniolite $\left(\mathrm{NaT}, \mathrm{NaMg}_{2} \mathrm{LiSi}_{4} \mathrm{O}_{10} \mathrm{~F}_{2}, n \mathrm{H}_{2} \mathrm{O}\right)$ and sodium hectorite ( $\mathrm{NaH}$, $\mathrm{Na}_{1 / 3} \mathrm{Mg}_{8 / 3} \mathrm{Li}_{1 / 3} \mathrm{Si}_{4} \mathrm{O}_{10} \mathrm{~F}_{2} n \mathrm{H}_{2} \mathrm{O}$ ), exchanges their $\mathrm{Na}^{+}$, the interlayer cation, for $\mathrm{K}^{+}, \mathrm{Rb}^{+}, \mathrm{Ca}^{2+}, \mathrm{Ni}^{2+}$, and other cations in solutions. $\mathrm{NaT}$ shows remarkably high selectivity for $\mathrm{K}^{+}, \mathrm{Rb}^{+}$, and $\mathrm{Cs}^{+}$and $\mathrm{NaH}$ does for $\mathrm{Rb}^{+}$and $\mathrm{Cs}^{+}$. XAFS of the exchanged ions in $\mathrm{NaT}$ and $\mathrm{NaH}$ were analyzed and powder X-ray diffractions were measured to investigate the layer stacking. Characteristics of ion-exchange selectivity of these micas were revealed by the local structure of the interlayer ion. $\mathrm{Rb}$ K-edge EXAFS of all samples show slightly longer $\mathrm{Rb}-\mathrm{O}_{1 \mathrm{st}}$ distance than $\mathrm{K}-\mathrm{O}_{1 \mathrm{st}}$ in taeniolite (its original anhydrous $\mathrm{K}$-form). It indicates that $\mathrm{Rb}^{+}$for the micas is exchanged as an anhydrous state. $\mathrm{X}$-Ray diffraction patterns showed hydrated interlayer-ion phases at low-exchanged $\mathrm{NaT}$ and $\mathrm{NaH}$. The hydrated phases decreased with increasing the exchange ratio and then less-hydrous $\mathrm{Rb}$-phase increased. Although $\mathrm{Cs}^{+}$-exchanged $\mathrm{NaT}$ show only an anhydrous state in $\mathrm{XAFS}, \mathrm{Sr}^{2+}$ and $\mathrm{Ba}^{2+}$ in $\mathrm{NaT}$ was hydrous as if in aqueous solution.
\end{abstract}

\section{INTRODUCTION}

Inorganic ion exchangers have their specific ion-selectivity to exchange reaction. $\mathrm{Na}$-form taeniolite $\left(\mathrm{NaT}_{1} \mathrm{NaMg}_{2} \mathrm{LiSi}_{4} \mathrm{O}_{10} \mathrm{~F}_{2} \cdot n \mathrm{H}_{2} \mathrm{O}\right)$ exchanges its $\mathrm{Na}^{+}$, the interlayer cation, for $\mathrm{K}^{+}, \mathrm{Rb}^{+}, \mathrm{NH}_{4}^{+}$, etc. in solutions. $\mathrm{Na}$-form hectorite $\left(\mathrm{NaH}, \mathrm{Na}_{1 / 3} \mathrm{Mg}_{8 / 3} \mathrm{Li}_{1 / 3} \mathrm{Si}_{4} \mathrm{O}_{10} \mathrm{~F}_{2} \cdot n \mathrm{H}_{2} \mathrm{O}\right)$ exchanges for $\mathrm{Rb}^{+}, \mathrm{Cs}^{+}$, and other cations. NaT shows especially high selectivity for $\mathrm{K}^{+}, \mathrm{Rb}^{+}, \mathrm{Cs}^{+}$, and $\mathrm{NH}_{4}{ }^{+}$, and $\mathrm{NaH}$ does for $\mathrm{Rb}^{+}$ and $\mathrm{Cs}^{+}$. According to diffraction, reaction heat, and thermal gravimetric studies, it is anticipated that the local structure of the exchanged ions affects the selectivity for ion-exchange reactions. In this study, $\mathrm{NaT}$ and $\mathrm{NaH}$ were exchanged for $\mathrm{Rb}^{+}, \mathrm{Cs}^{+}$, and other cations. The structural changes were studied by XAFS of the exchanged ion and powder X-ray diffraction patterns to reveal the relation of their ion-exchange selectivity and the local structure around the interlayer ions.

\section{EXPERIMENTAL}

Commercially available fluorine micas were used after removing impurities such as $\mathrm{SiO}_{2}(t e t r a)$ or starting materials by washing with water followed by separation with centrifugation. Rubidium, caesium, strontium, and barium chloride solutions were used for the reactions under $25^{\circ} \mathrm{C}$. Exchange ratios of $\mathrm{Rb}^{+}$to $\mathrm{Na}^{+}$in the micas were varied from $0.5 \%$ to the maximum. For another cations, exchange ratios were $40 \%$ and 55\%. X-Ray absorption spectra of $\mathrm{Rb}$ and $\mathrm{Sr} \mathrm{K}$-edge and $\mathrm{Cs}$ and $\mathrm{Ba}$ Lm-edge were obtained at BL-10B and BL-7C in the Photon Factory of the National Laboratory for High Energy Physics. EXAFS Fourier transforms were performed according to the procedures in the reference [1]. X-Ray powder diffraction patterns were measured by Rigaku RINT Ultima ${ }^{+}$. Rb- and Cs-exchanged NaT or $\mathrm{NaH}$ were prepared to be wet with the exchange reaction solution or deionized water, respectively, for both measurements, because they show structural changes in $\mathrm{X}$-ray diffraction with drying.

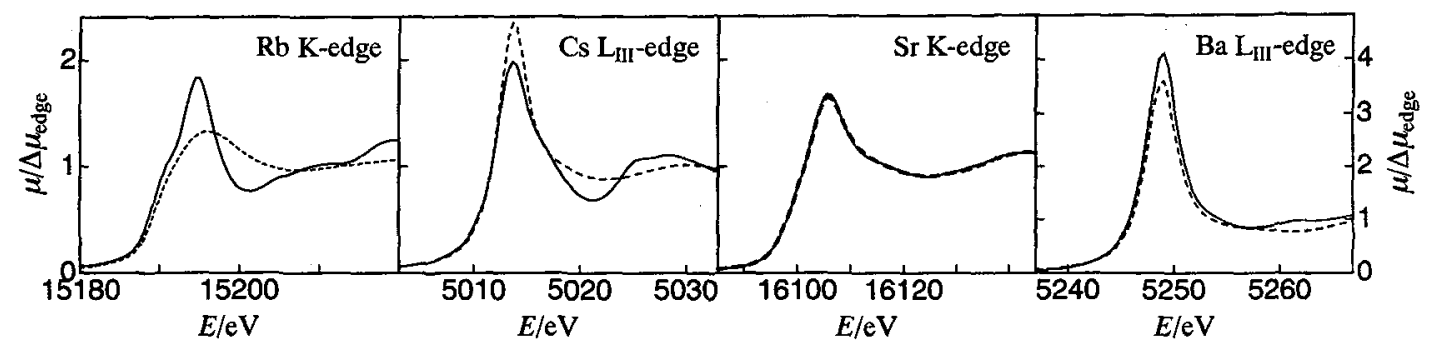

Figure 1. XANES spectra of ion-exchanged NaT (solid lines) and nitrate or chloride aqueous solution (broken lines). 


\section{RESULTS AND DISCUSSION}

Figure 1 shows XANES spectra of $\mathrm{Rb}$ and $\mathrm{Sr} \mathrm{K}$-edge and $\mathrm{Cs}$ and $\mathrm{Ba}$ $\mathrm{L}_{\text {m- }}$-edge uptaken into $\mathrm{NaT}$ and their $0.1 \mathrm{~mol} / \mathrm{dm}^{3}$ nitrate or chloride solutions. XANES of Rb- and Cs-exchanged $\mathrm{NaT}$ are apparently different from those of aqueous solution whereas those of Sr- and Ba-exchanged ones are similar. It shows that $\mathrm{Rb}$ and $\mathrm{Cs}$ take another local structure than in the solution state. The exchanged $\mathrm{NaT}$ of all exchange ratio for each exchange ion showed identical XANES spectra. EXAFS Fourier transforms of exchanged NaT are shown in Fig. 2. There is a large peak at the identical position with that in aqueous solution in the transform of $\mathrm{Sr}$ and $\mathrm{Ba}$-exchanged $\mathrm{NaT}$. These cations are hydrated as if in aqueous solutions. $\mathrm{Rb}$ and $\mathrm{Cs}$-exchanged $\mathrm{NaT}$ show many peaks in the transform. According to the crystal structure of $\mathrm{K}$-type taeniolite, $\mathrm{KMg}_{2} \mathrm{LiSi}_{4} \mathrm{O}_{10} \mathrm{~F}_{2}$ [2], these peaks can be assigned as Fig. 2 (a) indicates. Rb-exchanged NaT show no peak or shoulder for the hydrated water oxygen at the position for aqueous solution. After drying at $500^{\circ} \mathrm{C}$, the maximum Rb-exchanged $\mathrm{NaT}$ also shows the same

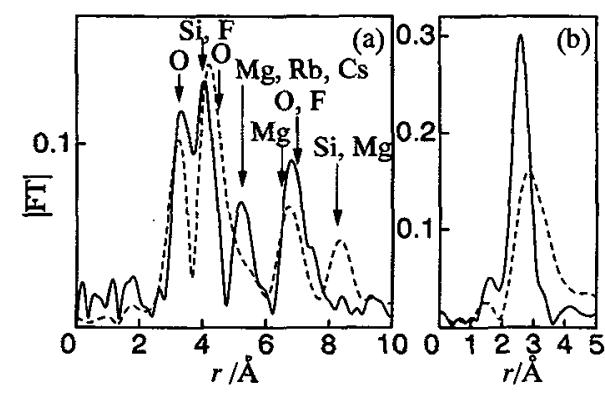

Figure 2. EXAFS Fourier transform of ion-exchanged NaT for $\mathbf{R b}$ (solid line) and Cs (broken) (a), and Sr (solid) and $\mathrm{Ba}$ (broken) (b). Phase shifts are corrected for each absorbing atom and $\mathrm{O}$ as the scatterer. $\mathrm{Li}$ atoms lie at the same position to $\mathrm{Mg}$ in (a). characters to Figs. 1 and 2. These alkaline cations are held as an anhydrous form.

$\mathrm{X}$-Ray diffraction patterns around basal plane reflection, ie., (001) diffraction of $1 \mathrm{M}$-type mica, of $\mathrm{NaT}$ and $\mathrm{NaH}$ after $\mathrm{Rb}$-exchange reaction for the low and the high exchange ratios are shown in Fig. 3. NaT show two- $\left(2 \theta \approx 5.8^{\circ}\right)$, one- $\left(7.4^{\circ}\right)$, or no-water layer $\left(9.2^{\circ}\right)$ phase of $\mathrm{Na}$-form taeniolite and anhydrous $\mathrm{Rb}$-form phase $\left(8.7^{\circ}\right)$ owing to their exchange ratio. $\mathrm{NaH}$ gives only $\mathrm{Rb}$-form hectorite phase with two- $\left(2 \theta \approx 5.7^{\circ}\right)$, one- $\left(6.9^{\circ}\right)$, or no-water $\left(8.6^{\circ}\right)$ layers. In both micas, the two-water layers decrease with increasing the ratio, the less-hydrous layers increase instead. From the diffraction pattern changes with the exchange ratios, the layers of the micas containing water can exchange its $\mathrm{Na}^{+}$and they become an anhydrous form.

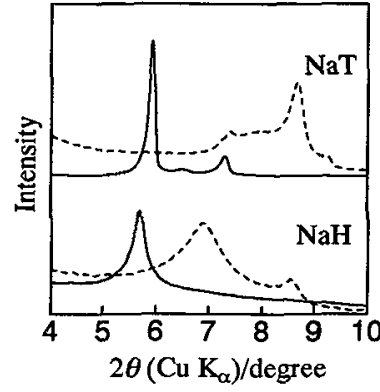

Figure 3. X-Ray diffraction parterns of Rb-exchanged $\mathrm{NaT}$ and $\mathrm{NaH}$. Exchange ratios are low (solid lines) and the maximum (broken lines).

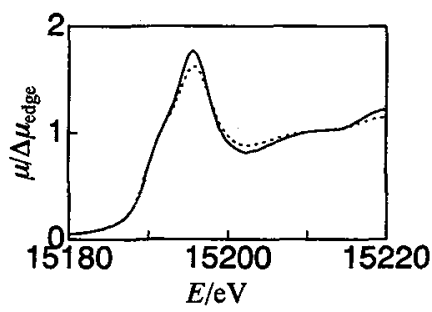

Figure 4. Rb K-edge XANES spectra of Rb-exchanged $\mathrm{NaH}$. Solid and broken lines show low and high exchange ratios, respectively.

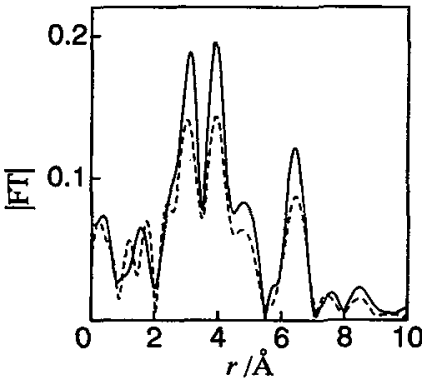

Figure 5. EXAFS Fourier transfoms of $\mathrm{Rb}$-exchanged $\mathrm{NaH}$. Phase shift is corrected as $\mathbf{R b}-\mathbf{O}$. Solid and broken lines show low and high exchange ratios, respectively.

From the information of XAFS and powder diffractions, a following mechanism of Rb-exchange reaction in $\mathrm{NaT}$ can be depicted. At the first stage, $\mathrm{Na}^{+}$in a two-water layer is exchanged for $\mathbf{R b}^{+}$. In this exchange reaction, $\mathbf{R b ^ { + }}$ detaches its hydration waters. When the ratio of $\mathbf{R b}^{+}$in the two-water layer reaches at a certain critical value, the layer begins excluding its interlayer waters until it become an anhydrous form. Finally, all the layers in a sample become anhydrous forms and then the whole exchange reaction stops.

Figure 4 shows XANES spectra of Rb K-edge uptaken into $\mathrm{NaH}$. It shows that $\mathbf{R b}$ takes another local structure than in the solution state. XANES for NaH of low exchange ratios were the same as $\mathrm{NaT}$, but those of the high ratios become somewhat similar to that for the aqueous solution. EXAFS Fourier transforms of exchanged $\mathrm{NaH}$ are shown in Fig. 5. When the exchange ratio is low, there is only small shoulder for the hydrated water oxygen at the position (about $2.8 \AA$ ) for the aqueous solution. Therefore, most of $R b^{+}$is placed as the anhydrous form in $\mathrm{NaH}$ at low exchange ratio. Hydrated $\mathrm{Rb}^{+}$in $\mathrm{NaH}$ increases with increasing the exchange ratio.

The diffraction pattern changes of $\mathrm{NaH}$ accord with those of NaT except the species of the interlayer cation. But, it is not consistent with the XAFS results. This inconsistency may be come from the difference of selectivity of the two methods. At the low exchange ratio, most of the $\mathrm{Rb}$-containing layers of $\mathrm{NaH}$ are anhydrous but would be spread randomly in the sample. Therefore, there is no diffraction peak at $2 \theta \propto 8.6^{\circ}$ at low exchange ratios.

\section{References}

[1] Sakane H., Miyanaga T., Watanabe I., Matsubayashi N., Ikeda S., and Yokoyama Y., Jpn. J. Appl. Phys., Part 1, 32 (1993) $4641-4647$.

[2] Toraya M., Iwai S., and Marumo F., Z. Kristallogr., 146 (1977) 73. 